\title{
Aplikasi Seven Tools pada Perbaikan Mutu Roundness Bakso Unyil di PT X
}

\section{Seven Tools's Application for Roundness Quality Improvement of Small Meatball Production in PT X}

\author{
Tjahja Muhandri ${ }^{1,2 *}$, Andika Putra Pratama ${ }^{1 \sharp}$, dan Dase Hunaefi ${ }^{1,2 \sharp}$ \\ ${ }^{1}$ Departemen Ilmu dan Teknologi Pangan, Fakultas Teknologi Pertanian, Institut Pertanian Bogor \\ ${ }^{2}$ Pusat Pengembangan Ilmu dan Teknologi Pertanian dan Pangan Asia Tenggara (Seafast Center), \\ Lembaga penelitian dan Pengabdian kepada Masyarakat, Institut Pertanian Bogor, \\ \# Jl. Kamper Kampus IPB Darmaga, Bogor 16680
}

\begin{abstract}
ABSTRAK
Mutu roundness Bakso Unyil yang diproduksi oleh PT X saat ini masih berada di bawah kompetitor. Perbaikan mutu roundness menjadi salah satu langkah yang dapat dilakukan untuk meningkatkan penerimaan konsumen. Penelitian ini bertujuan untuk mengidentifikasi penyebab rendahnya mutu roundness Bakso Unyil dan menemukan solusinya. Metode perbaikan mutu dilakukan tahapan, identifikasi penyebab rendahnya mutu roundness (Plan), uji coba perbaikan produksi (Do), dan implementasi tindakan perbaikan (Action). Sampel diambil sebanyak 20 buah bakso dari tiga batch (total 60 sampel). Analisis data menggunakan Diagram Ishikawa dan histogram. Implementasi alternatif perbaikan yang telah dilakukan, diantaranya penyesuaian jumlah adonan pada kuali mixing, pemasangan alat pengukur suhu di bak pemanasan awal, standarisasi penggunaan es, perbaikan teknik pencampuran fosfat dan garam, penghilangan penggunaan baking powder, dan pergantian jenis pisau di kuali mixing ternyata tidak hanya memperbaiki mutu roundness bakso Unyil tetapi juga memperbaiki kondisi pada permukaan Bakso Unyil yang berkerut dan tidak halus.
\end{abstract}

Kata kunci: bakso, mutu roundness, perbaikan mutu, seven tools

\section{ABSTRACT}

The roundness quality of small meatballs, called Bakso Unyil, produced by PT X has been considered non-uniform and in-competitive. Hence, roundness quality improvement has been becoming one of the priorities for increasing consumer acceptance. This research aims to identify the causes of the poor quality of Unyil Meatballs roundness and find a solution. The improvement methods were: identification of the causes of low quality of roundness (Plan), improvement trials based on alternative solution (Do), and implementation of corrective actions (Action). A total of 60 meatballs samples were taken from three batches (for each batch of 20 samples). Ishikawa Diagram, and histogram were conducted and analysed. Implementation of alternative solutions to improve roundness quality that have been carried out as follows: 1). adjusting the amount of dough in mixing step, 2). the installation of temperature measuring equipment in the preheater, 3). Usage standardization of ice, 4). improvement of phosphate and salt mixing techniques, 5). removal of baking powder, and 6). turn of blades in mixing cake. Result showed that those improvements were not only improve the roundness quality of Unyil meatballs but also improve the smoothness and reducing wrinkle conditions on the surface of Unyil meatballs.

Key words: meatball, quality improvement, roundness quality, seven tools

\section{PENDAHULUAN}

PT X yang berlokasi di Kota Tangerang merupakan salah satu industri menengah yang memproduksi bakso dengan target pasar menengah ke bawah. PT X menyadari dari sekian banyak jenis bakso yang di produksi, jenis bakso Unyil masih kalah bersaing dengan pesaing dalam hal kondisi fisik dan rasanya. Mutu kebulatan bakso (roundness) diduga menjadi salah satu faktor

\footnotetext{
*) Korespondensi:

Dept Ilmu dan Teknologi Pangan, Fateta IPB, Jl Kamper Kampus IPB Darmaga, Bogor 16680; email: cahyomuhandri@yahoo.com
} 
yang paling memengaruhi penerimaan konsumen. Perbaikan mutu roundness dari ketiga jenis bakso ini menjadi salah satu sorotan utama yang perlu diselesaikan untuk meningkatkan penerimaan konsumen dan daya saing di pasaran.

Menurut Juran dalam Muhandri dan Kadarisman (2012), mutu sebagai "fitness for use" yang artinya suatu produk atau jasa harus dapat memenuhi kebutuhan dan keinginan pelanggan. Menurut Crosby dalam Muhandri dan Kadarisman (2012), mutu sebagai "conformance to requirement", artinya suatu perusahaan harus mencoba mengerti dan memenuhi harapan konsumen dan melalui pandangan eksternal penyusunan sasaran mutu didesain secara realistis dan tetap sesuai dengan keinginan dan kebutuhan konsumen. Kegiatan perbaikan mutu saat ini menjadi hal pokok yang perlu diperhatikan oleh perusahaan, karena efek efisiensi produksi akan lebih nyata pada industri kecil dan menengah dibanding dengan industri yang sudah besar (Hung dan Sung, 2011).

Metode perbaikan mutu yang paling terkenal dan sering digunakan adalah siklus PDCA (Plan, Do, Check, and Action). Konsep ini dikembangkan oleh Dr. Walter Edwards Deming yang kemudian dikenal dengan 'The Deming Wheel", dimana siklus PDCA merupakan sebuah proses sederhana untuk terus mendukung pening-katan kearah perbaikan (Kurniawan, 2010). Penerapan prinsip dari metode PDCA ini digunakan sebagai acuan dalam melakukan peningkatan mutu di industri ini. Menurut Muhandri dan Sefrina (2016), penerapan konsep PDCA mampu memecahkan masalah umur simpan ayam kremes dan memperpanjang umur simpan dari 10 jam menjadi 72 jam. Tujuan penelitian ini adalah menerapkan prinsip perbaikan mutu PDCA untuk meningkatkan mutu roundness pada bakso jenis Unyil di PT X.

\section{METODE PENELITIAN}

Penelitian dilaksanakan di UD Sariwangi yang beralamat di Jl. KH Ahmad Dahlan, Kampung Cantiga, Kelurahan Petir, Kecamatan Cipondoh, Kota Tangerang 15147 selama empat bulan terhitung mulai tanggal 1 Februari sampai 31 Mei 2017.

\section{Identifikasi faktor penyebab rendahnya mutu roundness (Plan)}

Identifikasi dilakukan melalui kegiatan diskusi dengan karyawan yang telah berpengalaman dan tenaga ahli bidang terkait juga dilakukan dalam tahap ini. Hasil yang diperoleh disajikan dalam bentuk diagram sebab-akibat (Ishikawa). Pembuatan Diagram Ishikawa digunakan untuk mengidentifikasi seluruh faktor penyebab yang berpeluang mengakibatkan rendahnya mutu roundness bakso Unyil.

\section{Uji coba perbaikan produksi (Do)}

Kegiatan yang dilakukan pada tahap ini diawali dengan melakukan diskusi mengenai alternatif perbaikan yang dapat diterapkan dengan pihak industri. Tahap perbaikan dilakukan melalui perubahan pada faktor-faktor yang menjadi penyebab timbulnya masalah. Percobaan dilakukan langsung pada area produksi dan penarikan sampel pada produk akhir dilakukan secara acak dari setiap batch percobaan.

\section{Analisis simpulan statistik (Check)}

Analisis data menggunakan beberapa alat, seperti Ms. Excel, histogram dan diagram kendali. Pembuatan histogram dilakukan untuk mentabulasikan sebaran data perbandingan diameter terpanjang (D1) dan diameter terpendek (D2) bakso. Histogram dibuat dengan perangkat lunak Ms. Excel 2010. Alternatif perbaikan dianggap berhasil jika percobaan perbaikan mampu meningkatkan mutu roundness bakso dengan menggeser sebaran data pada histogram ke arah kiri (mendekati nilai satu).

\section{Implementasi alternatif perbaikan (Action)}

Alternatif yang telah berhasil meningkatkan mutu roundness bakso dipilih dan kemudian diterapkan sebagai standar baru dalam industri dengan tetap mempertimbangkan kondisi rill yang dialami industri.

\section{HASIL DAN PEMBAHASAN}

\section{Identifikasi Penyebab Rendahnya Mutu Roundness}

Tahap ini bertujuan untuk menelusuri faktor-faktor yang menjadi penyebab terjadinya masalah pada mutu roundness bakso beserta data kuantitatifnya. Hal ini dilakukan karena sifat mutu tekstur/bentuk bakso memiliki peringkat ketiga setelah rasa dan aroma terhadap penerimaan konsumen (Hermanianto dan Andayani, 2002). Alat yang digunakan dalam tahap ini berupa diagram sebab akibat (Diagram Ishikawa) dan histogram. Faktor-faktor yang ditemukan selama proses adalah empat faktor yang ditampilkan pada Gambar 1. 


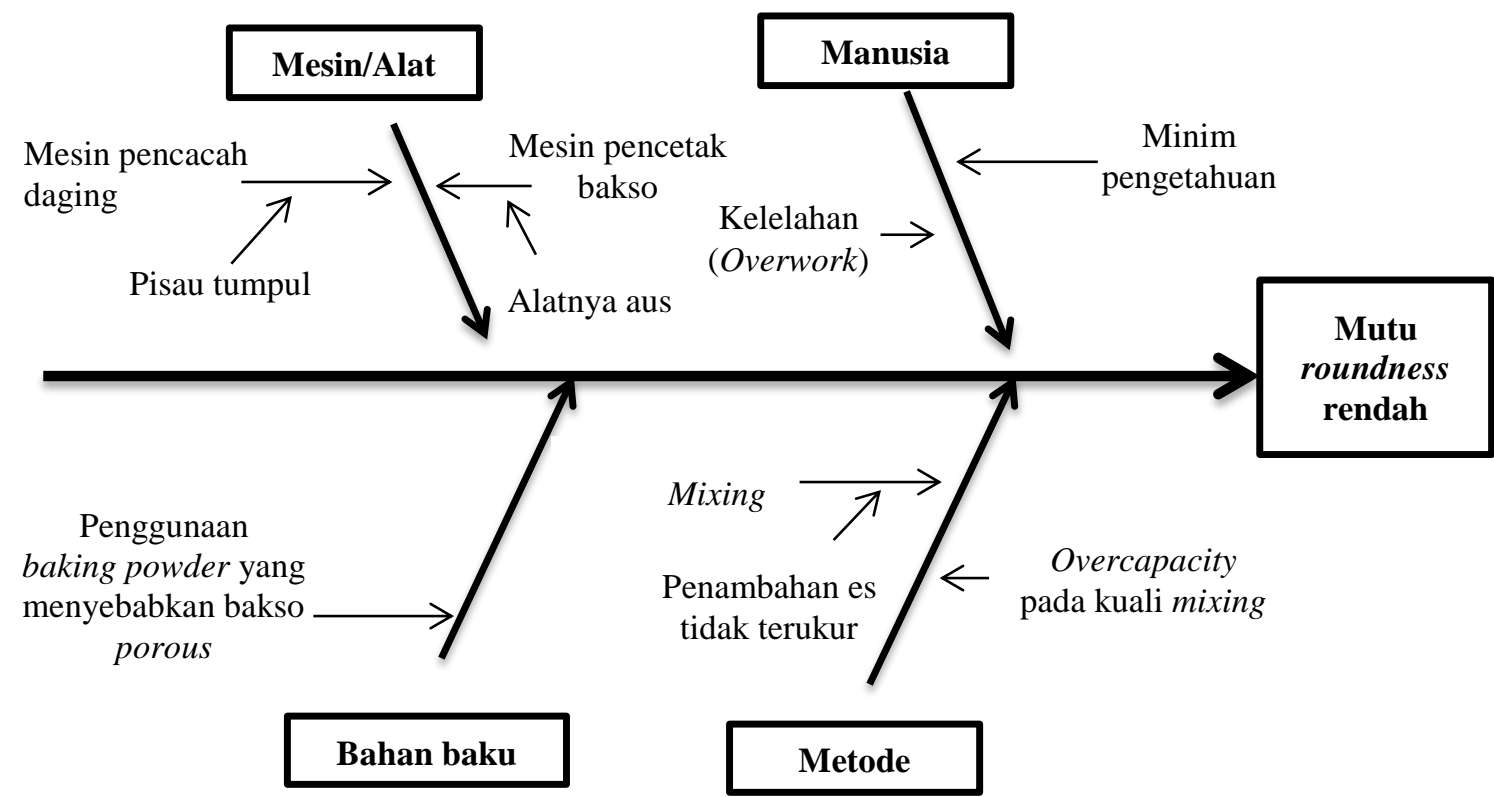

Gambar 1. Diagram Ishikawa penyebab mutu roundness bakso yang rendah di PT X

\section{Faktor Mesin}

Masalah yang dominan dari faktor mesin berasal dari mesin pencacah daging dan mesin pencetak beserta bak pemanasannya Jenis pisau yang digunakan pada mesin pencacah daging menyerupai gergaji dengan bagian sisi tajam yang menyebabkan pada saat penghalusan adonan terjadi gaya pukul (Gambar 2), sehingga pada adonan yang mengandung daging cukup tinggi tidak dapat dihaluskan dengan sempurna. Mesin pencetak juga mengalami keausan pada batang penahan selongsong pencetak bakso yang dihubungkan oleh gerigi dan rantai ke motor, sehingga selongsong tidak dapat berputar dengan baik untuk menghasilkan bakso yang berbentuk bulat.

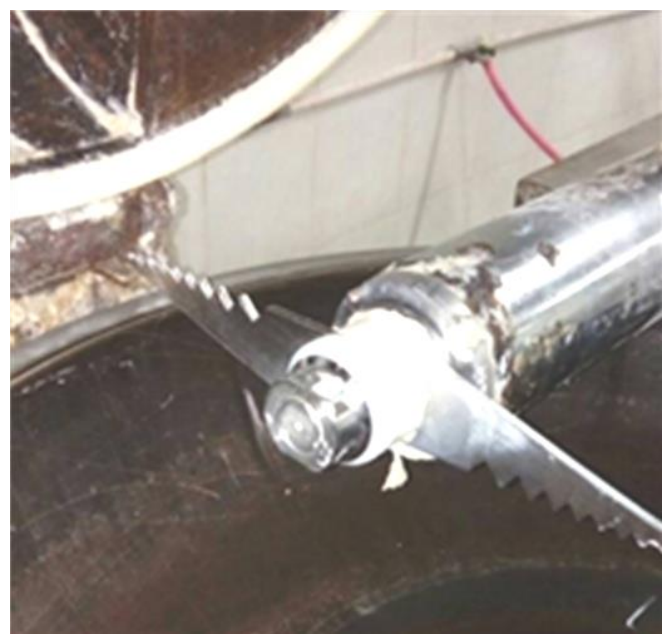

Gambar 2. Bentuk pisau yang digunakan pada mesin pencacah daging

\section{Faktor Bahan Baku}

Faktor bahan baku yang menjadi dugaan penyebab masalah mutu roundness bakso adalah penggunaan baking powder. Baking powder merupakan natrium bikarbonat $\left(\mathrm{NaHCO}_{3}\right)$ yang telah ditambahkan asam dan akan bereaksi dengan air menghasilkan gas $\mathrm{CO}_{2}$ (Hooker, 2008).

Menurut Pambudi dan Widjanarko (2015), penambahan natrium bikarbonat sebagai bahan pengembang menyebabkan terbentuknya gas $\mathrm{CO}_{2}$ sehingga tekstur menjadi porous, dan gas ini akan menguap ketika mengalami pemanasan. Penggunaan natrium bikarbonat $\left(\mathrm{NaHCO}_{3}\right)$ pada pembuatan bakso, diduga akan menyebabkan pembentukan rongga, sehingga ruang yang ditinggalkan oleh gas $\mathrm{CO}_{2}$ menyebabkan bakso memiliki permukaan yang tidak bulat sempurna.

\section{Faktor Metode}

Inkonsistensi viskositas adonan pada tahap mixing dipengaruhi oleh penambahan es yang belum distandarisasi. Adonan yang terlalu encer (penambahan es berlebih) berpotensi menghasilkan bakso yang tidak berbentuk bulat sempurna akibat tekanan dan benturan yang dialami ketika bakso keluar dari mesin pencetak. Hal ini juga diperburuk dengan penggunaan natrium bikarbonat (baking powder). Menurut Putranto et al. (2013), penurunan kadar air suatu produk akan lebih cepat dengan penggunaan baking powder.

\section{Faktor Manusia}

Kondisi SDM perusahaan yang terdiri dari lulusan SMA bahkan SMP dan SD membuat keterbatasan mengenai pengetahuan teknologi dan 
proses produksi bakso, sehingga hampir semua lini produksi dijalankan berdasarkan pengalaman tanpa ada staf ahli yang mengontrol jalannya poduksi. Kelelahan pekerja yang terjadi disebabkan karena manajemen waktu dan sistem yang kurang baik, sehingga mengakibatkan kasus overwork hingga 15 jam per hari.

Analisis kuantitatif dilakukan untuk membuktikan kondisi bentuk bakso yang tidak seragam, yaitu dengan mengukur perbandingan diameter terpanjang (D1) dan diameter terpendek (D2) dari bakso sehingga akan diperoleh nilai yang mendekati 1 (satu) jika bentuk bakso semakin mendekati sempurna. Pengukuran ini dilakukan pada tiga batch produksi di PT X yang kemudian dibandingkan dengan hasil pengukuran Bakso Bangka produksi PT Y.

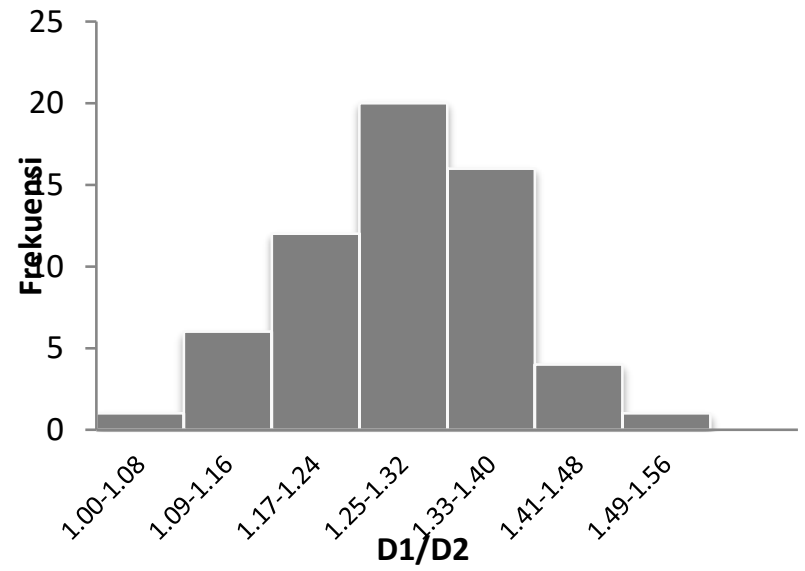

Gambar 3. Histogram perbandingan D1 dan D2 bakso unyil PT X

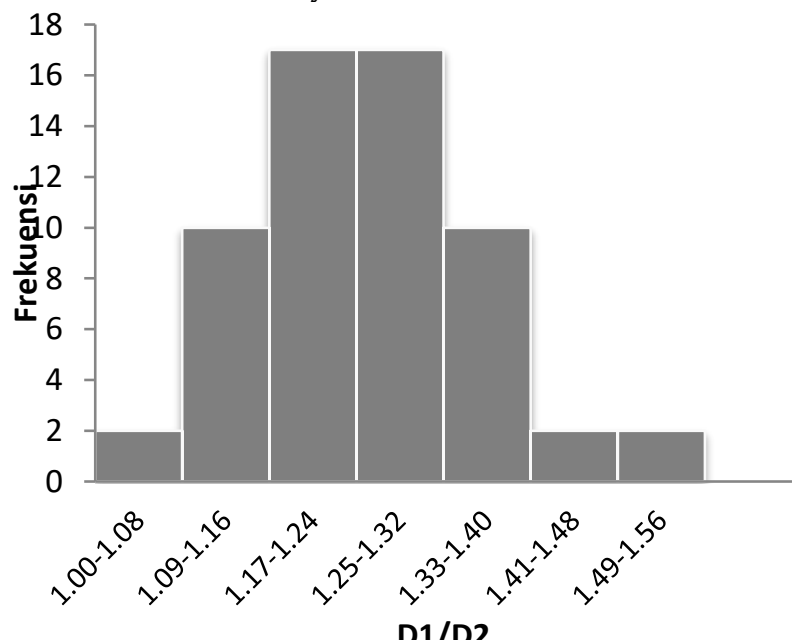

Gambar 4. Histogram perbandingan D1 dan D2 bakso unyil (Bangka) PT Y

Histogram pada Gambar 3 menunjukkan rataan perbandingan D1 dan D2 sebesar 1.25. Frekuensi tertinggi dari perbandingan diameter bakso unyil PT X berada pada selang 1.25-1.32 sebanyak $33.33 \%$, sedangkan frekuensi tertinggi dari perbandingan diameter bakso PT Y (Gambar 4) pada selang nilai yang sama sebanyak $28.33 \%$. Kegiatan perbaikan dilakukan untuk meningkatkan mutu roundness supaya lebih konsisten, sehingga diperoleh sebaran data yang berada pada rentang nilai yang semakin kecil dengan peningkatan persentase frekuensi terbanyak.

\section{Uji Coba Perbaikan Produksi}

\section{Faktor mesin}

Mesin pencetak merupakan salah satu mesin yang sangat berperan dalam menentukan mutu roundness bakso. Mekanisme kerja pembentukan bulat bakso pada mesin pencetak sangat ditentukan oleh putaran dari selongsong pencetak yang dihubungkan ke motor penggerak (Gambar 5). Apabila putaran pada selongsong pencetak ini terhambat, maka proses pembulatan bakso menjadi tidak optimal. Tingginya frekuensi penggunaan dari mesin ini yang dapat mencapai 15 jam per hari dan peremajaan yang tidak dilakukan dengan rutin menyebabkan mesin mengalami kelelahan lebih cepat, akibatnya terdapat bagian vital yang mengalami keausan pada batang penahan selongsong pencetak dan berpengaruh terhadap mutu roundness bakso (Gambar 6).
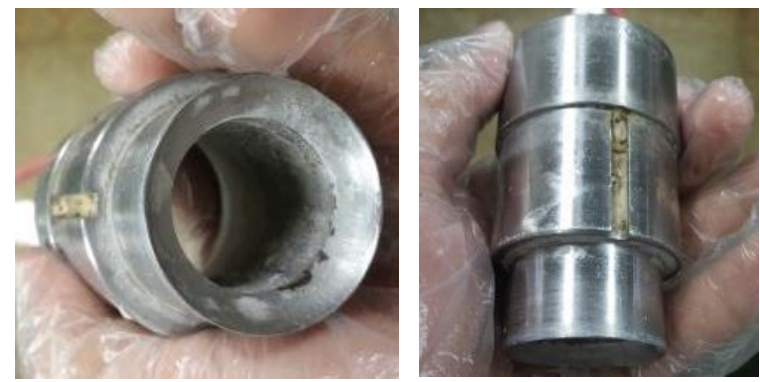

Gambar 5. Bentuk selongsong pencetak yang digunakan pada mesin pencetak

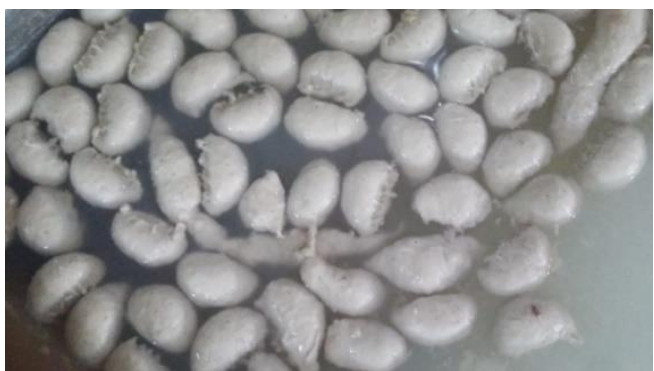

Gambar 6. Kondisi bakso yang dihasikan saat selongsong pencetak tidak berputar

Perbaikan yang diterapkan pada bagian ini adalah dengan mengelas bagian batang penahan 
supaya dapat menahan selongsong pencetak dan berputar dengan baik atau menggantinya dengan yang baru. Pergantian jenis pisau yang digunakan pada mesin pencacah daging juga perlu dilakukan, karena jenis pisau yang digunakan saat ini pada mesin pencacah daging kurang efektif apabila digunakan untuk memproduksi bakso yang memiliki kandungan daging tinggi. Pisau berbentuk sabit dengan salah satu sisi yang tajam dapat menjadi alternatif untuk digunakan dalam memproduksi bakso dengan kandungan daging (serat) tinggi. Penggunaan pisau jenis ini akan memberikan gaya sobek dan gaya pukul dalam satu waktu, sehingga adonan akan lebih halus dan merata meskipun kandungan dagingnya tinggi.

\section{Faktor bahan baku}

Penggunaan baking powder dalam pembuatan bakso merupakan hal yang belum banyak dilakukan. Perbaikan dirancang dengan mengkombinasikan pengaruh penambahan fosfat, garam, dan baking powder menjadi tiga sampel yang akan dianalisis mutu roundness (perbandingan diameter penjang dan diameter pendek) dan kehalusan permukaan bakso secara visual.

\section{Faktor metode}

STPP merupakan salah satu jenis fosfat yang paling sering digunakan sebagai bahan tambahan pangan dalam pembuatan bakso. Penambahan fosfat dapat meningkatkan kinerja produk berbahan daging, diantaranya mempertahankan kelembaban, memperbaiki warna, meningkatkan umur simpan dan meningkatkan daya ikat air (Long et al., 2011). Garam (NaCl) dapat memperbaiki sifat-sifat fungsional produk daging dengan mengekstrak protein myofibril dari sel-sel otot karena $\mathrm{NaCl}$ mampu memperluas ruang antar filament dalam protein myofibril sehingga terjadi pengembangan diameter myofibril (Sari dan Widjanarko, 2015). Penggunaan fosfat dapat ditambahkan di awal proses pengadukan bersamaan dengan garam dan es untuk meningkatkan kemampuan protein myofibril dalam mengikat air. Perbaikan ini dapat dilakukan dengan memisahkan wadah fosfat dan garam dengan wadah bumbu lain, dan dicampurkan terlebih dulu saat penggilingan daging.

Standarisasi penambahan es merupakan langkah perbaikan yang dilakukan pada jenis bakso unyil dengan mengacu pada pustaka dan perlakuan trial and error untuk menyesuaikan antara kebutuhan industri dengan pustaka yang diperoleh. Penambahan air es atau es batu dapat meningkatkan rendemen, maka dilakukan penambahan es sebanyak $10-15 \%$ atau bahkan $30 \%$ dari berat daging sampai adonan menjadi plastis dan mudah dibentuk. Observasi yang dilakukan pada tahap mixing menunjukkan bahwa penggunaan es mencapai 51,93\% dari campuran daging dan tepung. Percobaan dimulai dengan mengurangi kandungan es pada tingkat $50 \%, 45 \%, 40 \%$, dan $35 \%$. Penetapan kandungan es $40 \%$ dipilih oleh industri setelah melalui berbagai pertimbangan, kemudian dilakukan percobaan pada tiga batch di dua hari yang berbeda. Penarikan contoh dilakukan sebanyak 20 sampel dari setiap batch dan diukur diameter terpanjang (D1) dan terpendek (D2) untuk melihat perubahan sebaran data setelah perlakuan standarisasi penambahan es.

\section{Analisis Simpulan Statistik Standarisasi Penambahan Es}

Pengumpulan data pada percobaan perbaikan ini dilakukan pada tiga batch di hari yang berbeda dengan penggunaan es $40 \%$. Penarikan sampel pada setiap batch dilakukan sebanyak 20 sampel, dari setiap sampel dilakukan pengukuran perbandingan diameter terpanjang (D1) dan diameter terpendek (D2) yang disajikan pada Gambar 7. Data setelah perbaikan standarisasi penambahan es diperoleh rata-rata perbandingan D1 dan D2 sebesar 1,20 mm (lebih kecil dari sebelumnya 1,28 ).

Rentang kelas dengan frekuensi terbanyak bergeser dari 1,25-1,32 menjadi 1,17-1,24 menggambarkan keseragaman bentuk bulat bakso semakin baik. Hal ini menggambarkan konsistensi keseragaman bentuk bakso ikut meningkat.

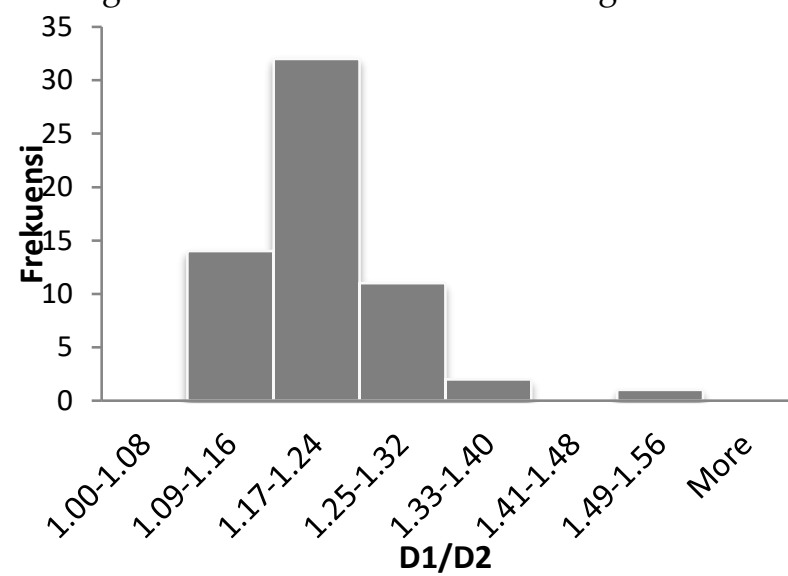

Gambar 7. Sebaran data D1/ D2 setelah standarisasi penambahan es

\section{Evaluasi penggunaan baking powder dan penambahan fosfat serta garam}

Percobaan pada tahap ini dilakukan pengukuran diameter terpanjang (D1) dan diameter 
terpendek (D2) dari masing-masing perlakuan dan disajikan dalam Gambar 8-10. Contoh A merupakan bakso yang tidak menggunakan baking powder dan pencampuran fosfat beserta garam dilakukan terpisah di awal. Sampel B merupakan bakso yang menggunakan baking powder dan pencampuran fosfat beserta garam dilakukan terpisah di awal.

Hasil menunjukkan sebaran data contoh A dan contoh B lebih baik dibandingkan dengan sebaran data dari contoh kontrol karena nilai terbanyak pada sampel A dan B berada di rentang kelas yang lebih kecil yaitu 1,17-1,24. Sebaran data perbandingan D1 dan D2 terlihat cenderung lebih kecil yang menunjukkan bentuk bulat bakso lebih baik. Namun, frekuensi bakso contoh A pada rentang kelas tersebut lebih besar (28,33\%) dibandingkan frekuensi contoh B pada rentang kelas yang sama (21,67\%). Hal ini menunjukkan perlakuan pada bakso contoh A memberikan hasil yang lebih baik dari bakso contoh B, dan bakso kontrol.

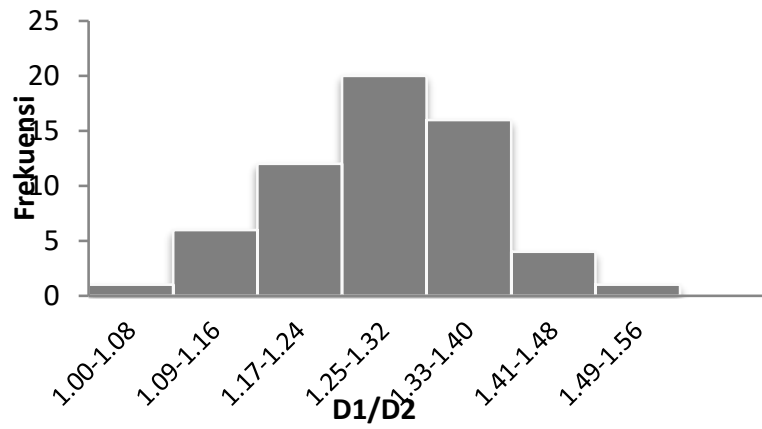

Gambar 8. Sebaran data D1/D2 untuk sampel bakso control (menggunakan baking powder dan pencampuran fosfat beserta garam dilakukan bersamaan dengan bumbu-bumbu lain, tidak dilakukan di awal)

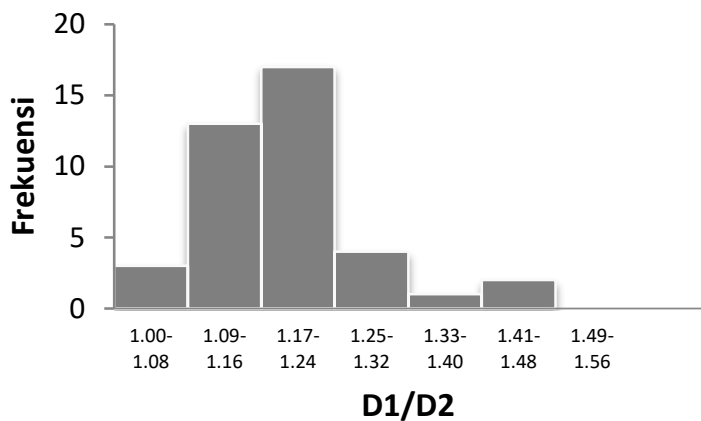

Gambar 9. Sebaran data D1/D2 untuk sampel bakso A (tidak menggunakan baking powder dan pencampuran fosfat beserta garam dilakukan terpisah di awal)

Permukaan bakso sampel kontrol memiliki tekstur yang kasar dan kondisi bakso dengan perlakuan $\mathrm{X}$ dan $\mathrm{Y}$ memberikan hasil penampakan permukaan yang lebih baik (Gambar 11). Bakso dengan kode sampel 327 (perlakuan X), yaitu bakso yang diberi perlakuan penambahan garam dan fosfat di awal tanpa penambahan baking powder adalah bakso yang memiliki mutu roundness dan mutu kehalusan permukaan paling bagus.

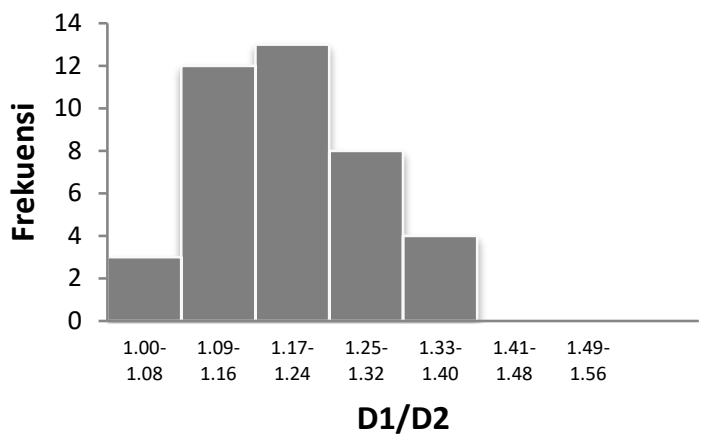

Gambar 10. Sebaran data D1/D2 untuk sampel bakso B (menggunakan baking powder dan pencampuran fosfat beserta garam dilakukan terpisah di awal)

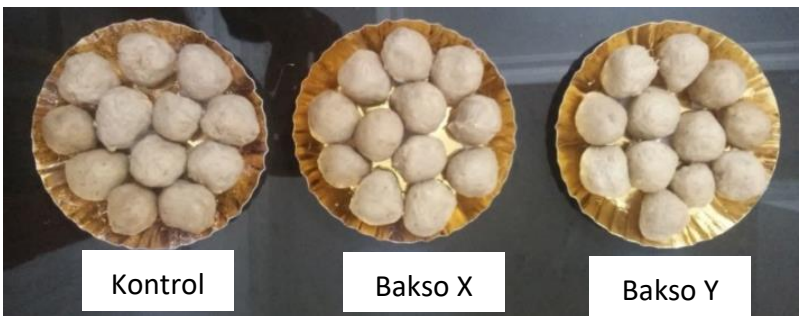

Gambar 11. Perbandingan penampakan bakso kontrol, sampel bakso $X$, dan sampel bakso $Y$

\section{Implementasi Tindakan Perbaikan}

Perbaikan mutu berdasakan hasil identifikasi permasalahan, sukses dilaksanakan di beberapa industri. Trisnowati et al. (2008) berhasil memperbaiki mutu roti di PT AC. Muhandri dan Rezki (2016) mampu meningkatkan mutu kripik balado melalui aplikasi perbaikan mutu PDCA.

Implementasi perbaikan telah dilakukan oleh PT X. Beberapa tindakan perbaikan yang telah diuji coba beserta kondisi penerapannya dapat dilihat pada Tabel 2.

Berbagai penerapan perbaikan yang telah dilakukan oleh industri ini dinilai memberikan dampak terhadap hasil penjualan produk. Perubahan positif yang dialami oleh perusahaan setelah menerapkan semua saran perbaikan kembali diamati dengan melakukan pengamatan terhadap penampakan fisik bakso dan mutu roundness bakso. 
Tabel 2. Beberapa tindakan perbaikan dan status penerapannya

\begin{tabular}{|c|c|c|c|}
\hline No. & Poin perbaikan & Kondisi awal & Kondisi terkini \\
\hline 1. & $\begin{array}{l}\text { Jumlah adonan per } \\
\text { batch }\end{array}$ & $\begin{array}{l}\text { Jumlah adonan mengalami } \\
\text { overcapacity pada mesin } \\
\text { mixing }\end{array}$ & $\begin{array}{l}\text { Jumlah adonan telah dikurangi } \\
\text { menjadi setengah bagian dari } \\
\text { adonan awal }\end{array}$ \\
\hline 2. & Penggunaan es & $\begin{array}{l}\text { Jumlah es dan air es yang } \\
\text { digunakan sangat tinggi dan } \\
\text { tidak konsisten }\end{array}$ & $\begin{array}{l}\text { Hanya menggunakan es } 40 \% \text { dan } \\
\text { telah dilakukan penimbangan } \\
\text { sebelum dicampurkan }\end{array}$ \\
\hline 3. & $\begin{array}{l}\text { Teknik penggunaan } \\
\text { fosfat }\end{array}$ & $\begin{array}{l}\text { Semua bahan kering } \\
\text { dicampur menjadi satu dan } \\
\text { dimasukan bersamaan ketika } \\
\text { di mesin mixing }\end{array}$ & $\begin{array}{l}\text { Wadah untuk garam dan fosfat } \\
\text { telah dipisah dengan bumbu lain, } \\
\text { lalu dimasukan terlebih dahulu } \\
\text { bersama daging dan sebagian es }\end{array}$ \\
\hline 4. & $\begin{array}{l}\text { Penggunaan baking } \\
\text { powder }\end{array}$ & $\begin{array}{l}\text { Digunakan dalam jumlah } \\
\text { sekitar } 0,2 \%\end{array}$ & Tidak digunakan lagi \\
\hline 5. & Alat pisau & $\begin{array}{l}\text { Perawatan tidak dilakukan } \\
\text { secara rutin, dan jenis pisau } \\
\text { yang digunakan tidak sesuai } \\
\text { dengan kebutuhan }\end{array}$ & $\begin{array}{l}\text { Mengganti jenis pisau jenis } \\
\text { pemukul menjadi pisau jenis } \\
\text { pemotong (Gambar } 12 \text { ) }\end{array}$ \\
\hline
\end{tabular}
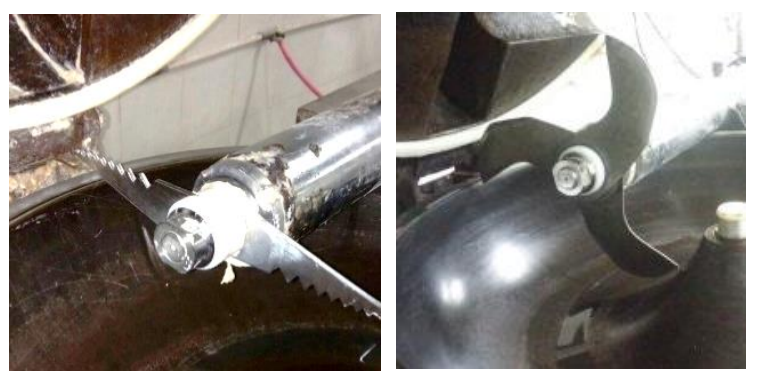

Gambar 12. Pisau pada mesin pencacah daging sebelum dan setelah diganti
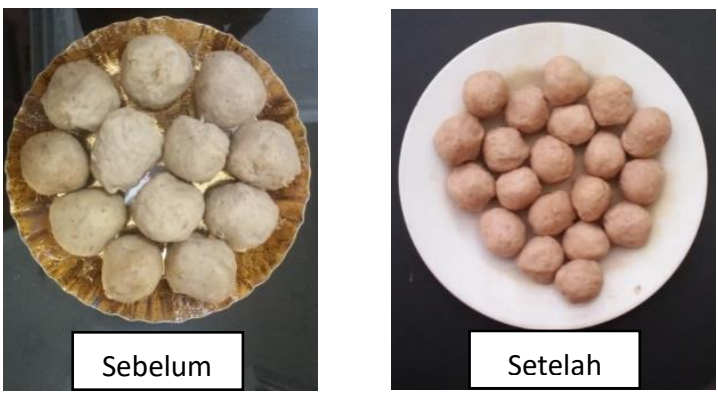

Gambar 13. Permukaan Bakso Unyil sebelum dan setelah perbaikan

Penampakan bakso pada Gambar 13 menunjukkan penampilan fisik bakso sebelum dan setelah perbaikan. Penampakan bakso Unyil setelah menerapkan berbagai perbaikan menghasilkan mutu roundness yang lebih baik dibanding dengan bakso Unyil sebelum menerapkan perbaikan. Kondisi permukaan bakso yang semula terdapat banyak kerutan (kasar) dan sisa-sisa serat daging yang tidak tergiling halus dapat diatasi dengan berbagai perbaikan sistem yang telah diterapkan.
Hasil perbaikan terhadap mutu roundness secara kuantitatif dapat menghasilkan nilai perbandingan D1 dan D2 yang lebih baik (Gambar 14). Sebaran data setelah perbaikan menunjukkan bahwa frekuensi terbanyak berada pada rentang kelas 1,17-1,24, yang nilainya lebih kecil dibanding sebaran data sebelum perbaikan $(1,25-1,32)$. Nilai perbandingan D1 dan D2 yang lebih kecil ini menunjukkan bentuk bakso yang semakin bulat sempurna. Rentang kelas dengan nilai lebih kecil, memiliki persentase frekuensi tertinggi yang diperoleh dari data setelah perbaikan mencapai $48.33 \%$, sedangkan persentase frekuensi dari data sebelum perbaikan pada kelas dengan rentang nilai yang lebih besar hanya mencapai $33.33 \%$.

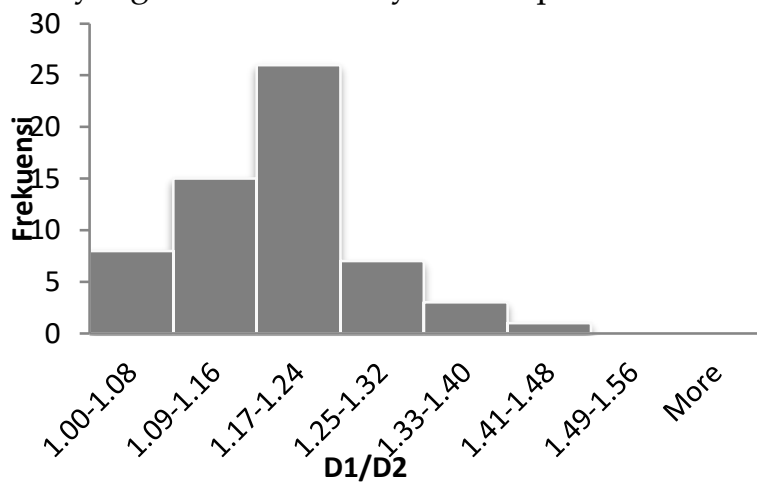

Gambar 14. Sebaran data D1/D2 Bakso Unyil setelah perbaikan

Hasil identifikasi permasalahan dan perbaikan mutu bakso Unyil di PT X digunakan untuk memperbaiki sistem yang telah berjalan selama ini bakso. Perbaikan meliputi penyusunan spesifikasi formula dan penyusunan Instruksi Kerja proses yang baru. 


\section{KESIMPULAN}

Perbaikan dan pengendalian proses produksi di PT $X$ dengan menerapkan prinsip PDCA telah mampu mengidentifikasi faktor-faktor penyebab mutu roundness Bakso Unyil yang kurang baik. Beberapa faktor yang diidentifikasi berasal dari mesin/peralatan, bahan baku dan metode. Uji coba perbaikan yang telah dilakukan, adalah dengan standarisasi penggunaan es, perbaikan teknik pencampuran fosfat dan garam, penghilangan penggunaan baking powder, dan pergantian jenis pisau pada mesin pencacah daging menunjukkan masalah mutu roundness dapat diatasi dengan baik. Hal ini ditunjukkan dengan sebaran data perbandingan diameter terpanjang dan terpendek dengan frekuensi tertinggi bergeser dari rentang kelas 1.25-1.32 (33.33\%) ke rentang kelas 1.17-1.24 (48.33\%). Mutu fisik lain seperti kerutan dan sisa-sisa serat daging yang tidak tergiling halus pada permukaan bakso juga dapat diatasi dengan berbagai implementasi perbaikan yang diterapkan. Bakso Unyil yang saat ini diproduksi telah memiliki mutu roundness yang lebih baik dan permukaan yang lebih halus.

\section{DAFTAR PUSTAKA}

Hermanianto, J., R.Y. Andayani. 2002. Studi perilaku konsumen dan parameter bakso sapi berdasarkan preferensi konsumen di wilayah DKI Jakarta. Jurnal Teknologi dan Industri Pangan. 8(1): 1-10.

Hooker, R. 2008. The Chemistry of Baking. New Zealand Institut (NZ): T.J. Edmonds Ltd.

Hung, H.C., M.H. Sung. 2011. Applying six sigma to manufacturing processes in the food industry to reduce quality cost. Scientific Research and Essays. 6(3): 580-591. DOI: 10.5897/SRE10.823.
Kurniawan, F. 2010. Pengendalian Kualitas: PDCA Cycle. Jakarta (ID): Pusat Pengembangan Bahan Ajar.

Long, N.H.B.S., R. Gal, F. Bunka. 2011. Use of phosphate in meat products. African Journal of Biotechnology. 10(86): 19874-19882. DOI: 10.5897/AJBX11.023

Muhandri, T., D. Kadarisman. 2012. Sistem Jaminan Mutu Industri Pangan. Bogor (ID): IPB Press.

Muhandri, T., M. Sefrina. 2016. Peningkatan umur simpan produk ayam kremes. Jurnal Agrokreatif. 2(1): 25-30.

Muhandri, T., O. Rezki. 2016. Perbaikan mutu dan penyusunan instruksi kerja pada pembuatan keripik sanjai balado Nina di Bukittinggi. Jurnal Agrokreatif. 2(1):1-6.

Pambudi, S., S.B. Widjanarko. 2015. Pengaruh proporsi natrium bikarbonat dan ammonium bikarbonat sebagai bahan pengembang terhadap karakteristik kue bagiak. Jurnal Pangan dan Agroindustri. 3(4): 1596-1607.

Putranto, A.W., B.D. Argo, N. Komar. 2013. Pengaruh perendaman natrium bikarbonat dan suhu penggorengan terhadap kekerasan keripik kimpul. Jurnal Teknologi Pertanian. 14(2): 105-114.

Sari, H.A., S.B. Widjanarko. 2015. Karakteristik kimia bakso sapi (kajian proporsi tepung tapioka: tepung porang dan penambahan $\mathrm{NaCl}$ ). Jurnal Pangan dan Agroindustri. 3(3): 784-792.

Trisnowati, H., M. Hubeis, H. Hardjomidjojo. 2008. Analisis pengendalian mutu produksi roti di PT AC. Jurnal MPI, 3(1): 51-61. 